\section{Polymorphism of maleic hydrazide. I. Erratum}

\author{
Andrzej Katrusiak ${ }^{\mathrm{a} *}$ \\ ${ }^{a}$ Department of Crystal Chemistry, Adam Mickiewicz University, Grunwaldzka 6, 60- \\ 780 Poznań, Poland
}

In the recently published article by Katrusiak (2001) the crystal data of two polymorphs of maleic hydrazide have been printed with errors or omissions in Tables 1 and 2 . It was the author's intention that the measurements of the unit-cell dimensions were possibly accurate, as the comparison of densities and unit-cell volumes of polymorphs are of particular importance. Therefore, these measurements were carried out at varied temperatures to eliminate possible differences owing to the thermal expansion of the crystals, and two different diffractometers, one with a point detector and another one with a CCD, were used to eliminate systematic errors. From these data the unit-cell dimensions at normal conditions were estimated and listed in Table 1, while the crystal data of the diffractometric experiments were duly related in Table 2. It was hoped that this procedure would provide the reader with reliable crystal data. Overestimated precision of routinely reported unit-cell dimensions has been extensively discussed by other authors (e.g. see Herbstein, 2000). The ambiguity resulting from different equipment, data collecting techniques, wavelengths etc. is further aggravated by the vague definition of the so-called room temperature. This temperature is assumed as $293 \mathrm{~K}$ and indeed this is the default value if not specified otherwise in programs writing CIF files, even though diffractometers are usually enclosed in safety boxes, where slowly circulating air is heated up by step motors, electronics, cables etc. or even by the X-ray tube if its heat is not totally balanced by the cooling system. Therefore, the temperature in the safety box is higher than outside: when the temperature in our laboratory is air-conditioned to $293 \mathrm{~K}$, the difference in temperatures outside and inside the safety box is $3.5^{\circ}$. Additionally, the temperature of the measurement, even when measured with high relative precision, may considerably differ from the absolute scale. Meanwhile, the crystal data in Tables 1 and 2 were treated as redundant and after acceptance of the manuscript the crystal data were removed from Table 2 in the proof. The author's request to include these missing data resulted in the multiple errors (Katrusiak, 2001). The correct tables, as originally submitted, are reproduced below.
Table 1

Crystal data and unit-cell dimensions at normal conditions $(298 \mathrm{~K})$ of the three polymorphs of maleic hydrazide.

\begin{tabular}{llll}
\hline & MH1 & MH2 & MH3 \\
\hline Crystal system & Triclinic & Monoclinic & Monoclinic \\
Space group & $P \overline{1}$ & $P 2_{1} / c$ & $P 2_{1} / n$ \\
$\quad a(\AA)$ & $5.797(3)$ & $6.892(2)$ & $6.604(1)$ \\
$b$ & $5.817(3)$ & $9.673(2)$ & $6.904(1)$ \\
$c$ & $7.307(3)$ & $6.960(1)$ & $10.534(4)$ \\
$\alpha\left({ }^{\circ}\right)$ & $78.82(3)$ & 90 & 90 \\
$\beta$ & $99.38(3)$ & $100.05(2)$ & $104.04(4)$ \\
$\gamma$ & $107.12(3)$ & 90 & 90 \\
$V\left(\AA^{3}\right)$ & $229.5(1)$ & 456.9 & $465.94(9)$ \\
$Z$ & 2 & 4 & 4 \\
$D_{x}\left(\mathrm{~g} \mathrm{~cm}^{-3}\right)$ & 1.622 & 1.630 & 1.599 \\
\hline
\end{tabular}

Table 2

Selected crystal data and structure refinements for MH1 and MH3.

\begin{tabular}{lll}
\hline & $\mathrm{MH} 1$ & $\mathrm{MH} 3$ \\
\hline Empirical formula & $\mathrm{C}_{4} \mathrm{H}_{4} \mathrm{~N}_{2} \mathrm{O}_{2}$ & $\mathrm{C}_{4} \mathrm{H}_{4} \mathrm{~N}_{2} \mathrm{O}_{2}$ \\
Formula weight & 112.09 & 112.9 \\
Temperature (K) & $300(1)$ & $300(2)$ \\
Wavelength $(\AA)$ & 0.71073 & 1.54178 \\
Crystal system, space group & Triclinic, $P \overline{1}$ & Monoclinic, $P 2_{1} / n$ \\
$\quad a(\AA)$ & $5.8181(10)$ & $6.6070(15)$ \\
$b(\AA)$ & $5.8000(10)$ & $6.9070(7)$ \\
$\quad c(\AA)$ & $7.3090(10)$ & $10.539(3)$ \\
$\alpha\left({ }^{\circ}\right)$ & $78.80(3)$ & 90 \\
$\beta\left({ }^{\circ}\right)$ & $99.36(3)$ & $104.00(4)$ \\
$\gamma\left({ }^{\circ}\right)$ & $107.13(3)$ & 90 \\
Volume $\left(\AA^{3}\right)$ & $229.74(6)$ & $466.68(17)$ \\
$Z$, calculated density $\left(\mathrm{g} \mathrm{cm}{ }^{-3}\right)$ & $2,1.620$ & $4,1.595$ \\
Absorption coefficient $\left(\mathrm{mm}^{-1}\right)$ & 0.133 & 1.128 \\
$F(000)$ & 116 & 232 \\
Crystal size (mm) & $0.5 \times 0.3 \times 0.15$ & $0.4 \times 0.4 \times 0.2$ \\
$\theta$ range for data collection $\left({ }^{\circ}\right)$ & $3.69-29.71$ & $7.21-61.97$ \\
Limiting indices $h, k, l$ & $-7 / 7,-7 / 8,-9 / 9$ & $0 / 6,0 / 7,-12 / 11$ \\
Reflections collected/unique & $2196 / 1153$ & $737 / 671$ \\
$R_{\text {int }}$ & 0.0454 & 0.0273 \\
Completeness to $\theta\left({ }^{\circ}\right)$ & $88.8 \%$ to 29.71 & $91.9 \%$ to 61.97 \\
Data/restraints/parameters & $1153 / 0 / 90$ & $671 / 0 / 89$ \\
Goodness-of-fit on $F^{2}$ & 1.010 & 1.093 \\
Final $R 1 / w R 2$ indices $\left(I>2 \sigma_{I}\right)$ & $0.0535 / 0.0823$ & $0.0475 / 0.0969$ \\
$R 1 / w R 2$ indices $($ all data) & $0.0869 / 0.0882$ & $0.0550 / 0.1036$ \\
Extinction coefficient & $0.035(13)$ & 0 \\
Largest difference peak/hole $\left(\mathrm{e} \AA^{-3}\right)$ & $0.30 /-0.22$ & $0.26 /-0.20$ \\
\hline & &
\end{tabular}

\section{References}

Herbstein, F. H. (2000). Acta Cryst. B56, 547-557. Katrusiak, A. (2001). Acta Cryst. B57, 697-704. 